\title{
ÜVEGKERÁMIÁS FőZŐLAPOK RAGASZTÁSA PLAZMA SUGÁRRAL KEZELT FÉMFELÜLETRE
}

\section{GLUING CERAMIC COOKTOP TO METAL SURFACES TREATED WITH PLASMA JET}

\author{
Pintye Gábor \\ Electrolux-Románia Szatmárnémeti: (Kolozsvári Müszaki Egyetem, Gépészmérnöki \\ Kar, Gyártás Technológiai Tanszék), Cím: 440187, Románia, Szatmárnémeti, \\ Drumul Careiului, szám 28/93; Telefon:+40-770469564,pintyegabor@yahoo.com
}

\begin{abstract}
Along with the development of science and technology, new materials and technical solutions, that exceed the traditional processing and installation solutions, have occurred, such as welding, riveting or screw fastening. Among non-traditional, modern processing technology we can mention the possibilities of laser processing, ultrasonic, electrical erosion, waterjet, plasma and other possibilities. These non-traditional processing technology have gradually replaced traditional processing methods, as they have many advantages. First of all, the number of scrap parts is minimal, processing time is shortened, the number of parts to be replaced and consumable parts is minimal and last but not least they are more environmentally friendly.
\end{abstract}

Keywords: Ceramic cooktop, gluing, roughness, plasma, roughness, testing tear strength.

\section{Összefoglalás}

A tudomány és a technika fejlődésével új anyagok és új technikai megoldások jelentek meg, maguk mögé utasítva a hagyományos megmunkálást illetve összeszerelési megoldásokat, mint például a hegesztést, a szegecselést és a csavarozást. Ilyen nem hagyományos, korszerü technológiai megmunkálások például a lézeres, az ultrahangos, a szikraforgácsolós, a vízsugaras, a plazmás illetve más egyéb lehetőségek. Ezek a nem hagyományos technológiai megmunkálások lassan-lassan felváltják a hagyományos megmunkálásokat mivel sok előnyük van. Először is minimális a selejtes alkatrészek száma, a megmunkálás időtartama lerövidül, a csere illetve fogyó alkatrészek száma minimális és nem utolsó sorban sokkal környezetbarátabb.

Kulcsszavak: Kerámialap, ragasztás, érdesség, plazma, érdesség, szakitás próba.

\section{1. Üvegkerámiás főzőlapok}

Az üvegkerámia körülbelül 20-25 éves múltra tekint vissza és leggyakoribb illetve legismertebb elterjedési formája a villanytüzhelyek munkafelülete illetve a beépithető fözölapok.

De mi is valójában az üvegkerámia?
Ez egy olyan anyag, mely az üveg és a kerámia között helyezkedik el és szabályozott kristályosítással készül. Az így kapott anyag az üvegkerámia lap, kiválóan ellenáll a gyors és ismétlődő hőmérsékletváltozásnak, és a $800{ }^{\circ} \mathrm{C}$, de akár az $1000{ }^{\circ} \mathrm{C}$ fokot is elviseli. Erős mechanikai tulajdonsággal rendelkezik például a húzó-nyíró (szakító) szilárdság: 


$$
\tau_{\text {hny }}=\frac{F_{\max }}{A_{o}}=200-250 \mathrm{MPa}
$$

Az üvegkerámiás fözőlapok a villanytüzhelyek esetében egy fémkereretbe vannak belefoglalva, pontosabban ragasztva (1. ábra).

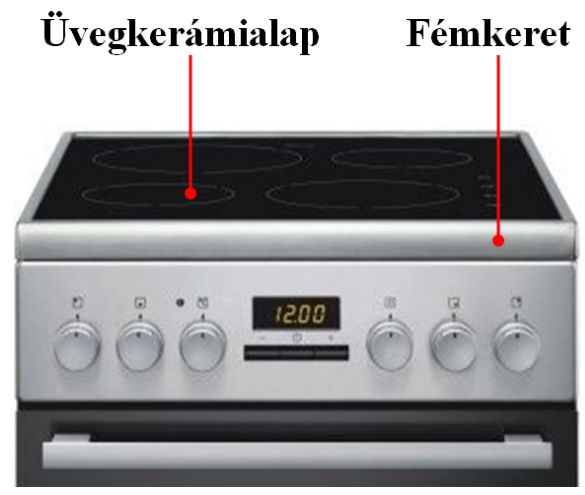

1. ábra. Villanytüzhely üvegkerámialappal

Jelenleg a szatmárnémeti tűzhelygyártó vállalatnál ez a fémkeret két anyagból készül:

- Rozsdamentes acél (ausztenites inox)

304-2B ASTM, (X5CrNi18-10);

- Hidegen hengerelt ötvözetlen lágyacél

(fekete lemez) DC 04 EK-M, (EN

10209).

A fekete lemezből készült fémkeret természtesen nem marad saját színében hanem kap egy festék réteget ami elektromágneses mezőben van felhordva.

\subsection{A ragasztástechnika alapjai}

A ragasztás két szilárd test összeerősítését jelenti ragasztó segítségével.

A felerósített részek anyaga nem szükséges, hogy azonos legyen. A ragasztott kötés tehát a ragasztandó anyagokból és a ragasztóból áll. A ragasztott kötések szilárdságát döntően két erő-típus adja: a ragasztandó anyagok, valamint a ragasztó belső szilárdsága, kohéziója és a ragasztandó anyag - ragasztó határfelületén fellépő erőhatások, az adhézió. Jó ragasztott kötésben az adhéziós erők legalább olyan nagyok, mint a kohéziós erők. Ez más szavakkal azt jelenti, hogy a jól összeragasztott anyagdarabokat nagy erőhatásnak kitéve a tönkremenetel (szakadás, törés) a ragasztandó darabban történik, és nem határfelületen, a ragasztó elválása miatt. [3].

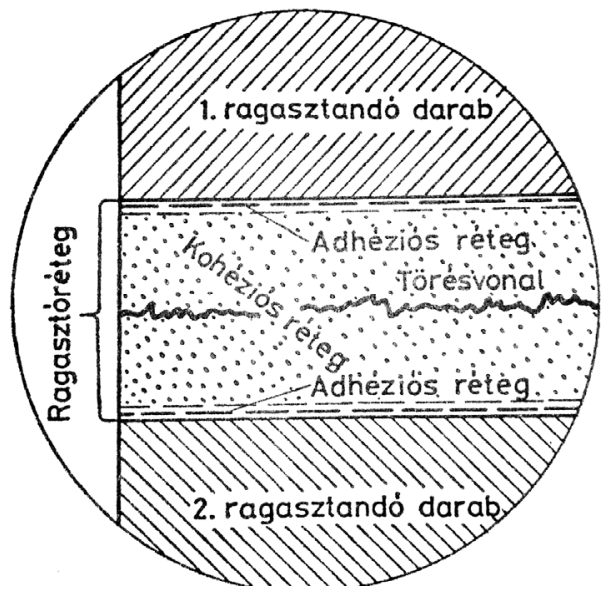

2. ábra. A ragasztóréteg felépitése

A ragasztott kötés keresztmetszete az 2. ábrán látható. A ragasztandó felülettel a ragasztó igen vékony úgynevezet adhéziós rétege érintkezik. A ragasztó belső, vastagabb rétege a kohéziós réteg. [1]. A mechanikai kapcsolódás elmélete szerint a hordozó és a ragasztó (vagy bármilyen bevonat, festék) között a kötést a bevonatnak a hordozó anyag felületi érdességébe, pórusaiba történő behatolása hozza létre. Azokban az esetekben, amikor ténylegesen kimutatható a ragasztó behatolása a felület egyenetlenségeibe, a mechanikai kapcsolódás hatására a tapadó erő növekedés jelentős lehet [3].

\subsection{Az üvegkerámialapok ragasztása}

Általában, mint minden új gyártási folyamat bevezetésénél, úgynevezet előre nem látott kellemetlenségek jelentkezhetnek. Ilyen kellemetlenséggel találkoztunk amikor minőség ellenőrzést végeztünk, 
pontosabban szakító próbát. A próbák elvégzésekor két negatív jelentséget tapasztaltunk: a ragasztó elválása és a adhéziós szakadás történt.

\subsubsection{A vizsgált munkadarab összetevői}

Az összeregasztott és megvizsgált munkadarab (félkész termék) három különböző anyag összeillesztésével jön létre ami a 3. ábrán látható.

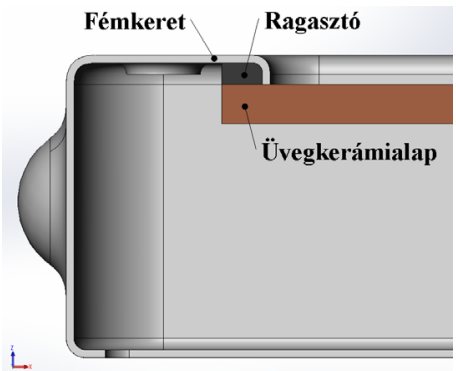

3. ábra. A vizsgált munkadarab, grafikai keresztmetszete

A munkadarab összetevői:

- Üvegkerámialap, EuroKera termék,[5];

- Ragasztó, Otto Chemie termék,[6];

- Fémkeret, saját termék.

\section{Korszerú plazma technológia}

A plazma technológia a korszerü megmunkálási technológiák csoportjába tartozik, úgy mint a lézeres, az ultrahangos vagy akár a vízsugaras.

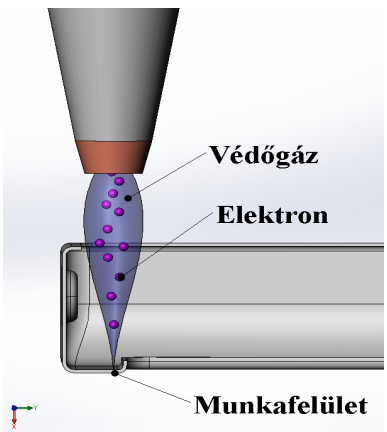

4. ábra. A munkadarad bombázása elektronokkal.
A megmunkálási folyamat a plazma technológiánál abban nyilvánul meg, hogy elektronok nagy sebességgel úgymond bombázzák a megmunkálásra szánt munkadarabot ami a (4. ábra). [2].

Ez a bombázás teljes vagy részleges anyag eltávolítást eredményezhet, amit plazma generátorral tudunk megvalósítani.

A plazma generátorok esetében megkülönböztetünk két megmunkálási folyamatot: - Plazma ívet, ami az elektróda (katód) és a munkadarab (anód) között alakúl;

- Plazma sugarat, ami az elektróda (katód) és düzni (anód) közöttjelenik meg [4].

A plazma íves megmunkálási folyamat legismertebb és legelterjedtebb formája a hegesztés, a vágás, a szabászat és vele járó mellékterméke a szikra ami külön védőszerelést igényel, míg a plazma sugaras technológiát felület kezelésre illetve érdesség megnövelésére alkalmazzuk, mivel mentes.

\subsection{Az érdesség növelése}

A tanulmányozott fémkeretek felületét elektronmikroszkóppal vizsgáltuk, plazma sugaras kezelés elött és utánna (5. és 6. ábra). Az eredményeket ImageJ programmal értékeltük ki..

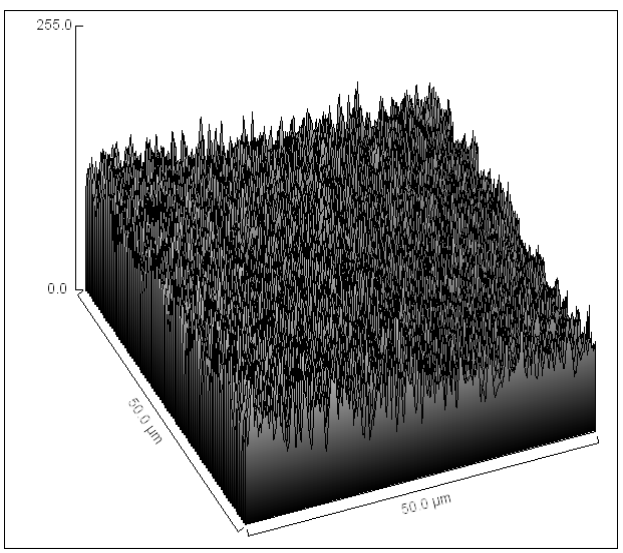

5. ábra. Az rozsdamentes fémkeret $250 \mu \mathrm{m}^{2}$ szelvénye plazma sugaras kezelés elött 1000-szeres nagyitással 


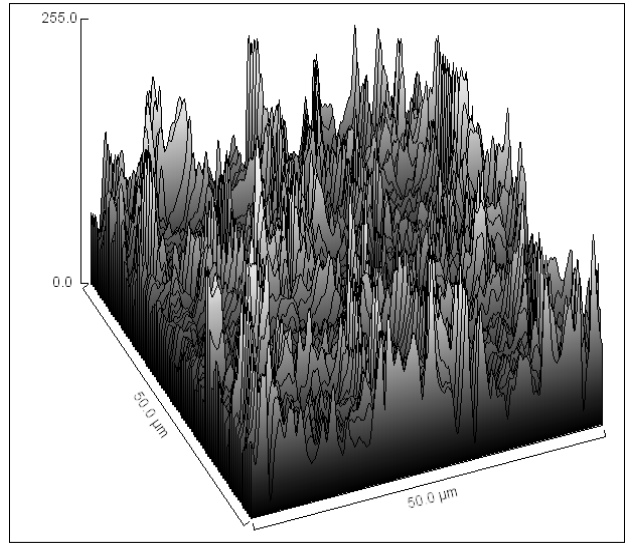

6. ábra. A rozsdamentes fémkeret $250 \mu^{2}$ szelvénye plazma sugaras kezelés után (1000-szeres nagyitás)

\section{Következtetések}

A mechanikai kapcsolódás elmélete alapján a ragasztó a felületi érdességekbe történő behatolása, folyásolja be a ragasztás mínőségét, erősségét. Az 5. illetve 6. ábrán a profil hegyek-völgyek elég rendezetek azonos nagyságúak, míg a plazma sugaras kezelés után a profil hegyek-völgyek teljesen rendezetlené és különbüző nagyságúakká válnak, ami nagyban megnöveli a ragasztás erősségét. A megismételt szakító próbák is ezt bizonyították, illetve kohéziós szakadást tapasztaltunk, ami a 7. ábrán látható.
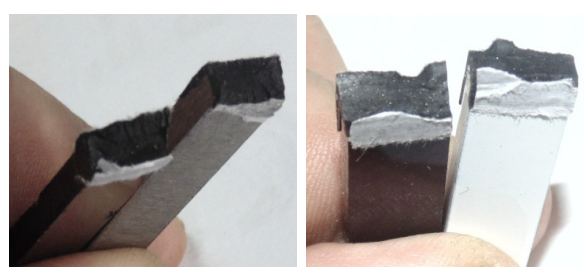

7. ábra. Kohézios szakadások az rozsdamentes illetve a festet mintadaraboknál, a plazma sugár kezelés után

A mai korszerü megmunkálási technológiák ismeretében mind arra törekszünk, hogy minél finomabb illetve kisebb értekü érdességi felületet kapjunk.

Ime egy ellenpélda amivel ,roncsoljuk” a felületet de a mechanikai tulajdonságok növelése érdekébben.

\section{Szakirodalmi hivatkozások}

[1] Balázs Gy.: Ragasztás technika. Müszaki Könyvkiadó, Budapest, 1982, 11-18.

[2] Bâlc N.: Tehnologii neconvenționale. Editura Dacia, Cluj-Napoca, 2001, 137-146.

[3]Czvikovszky T., Nagy P., Gaál J.: $A$ polimertechnika alapjai. Mủegyetemi Kiadó, Budapest, 2006, 12.3 A ragasztástechnika alapjai.

[4]Făgărășan C.: Studii și cercetări privind utilizarea instalațiilor cu jet de plasmă la debitarea diverselor tipuri de materiale. Teză de doctorat, UT-Cluj-Napoca, 2009 , 10-13.

[5] http://www.eurokera.com/manufacturing/

[6] http://www.otto-chemie.de/de/startseitebau/novasil-s-95.pdf 